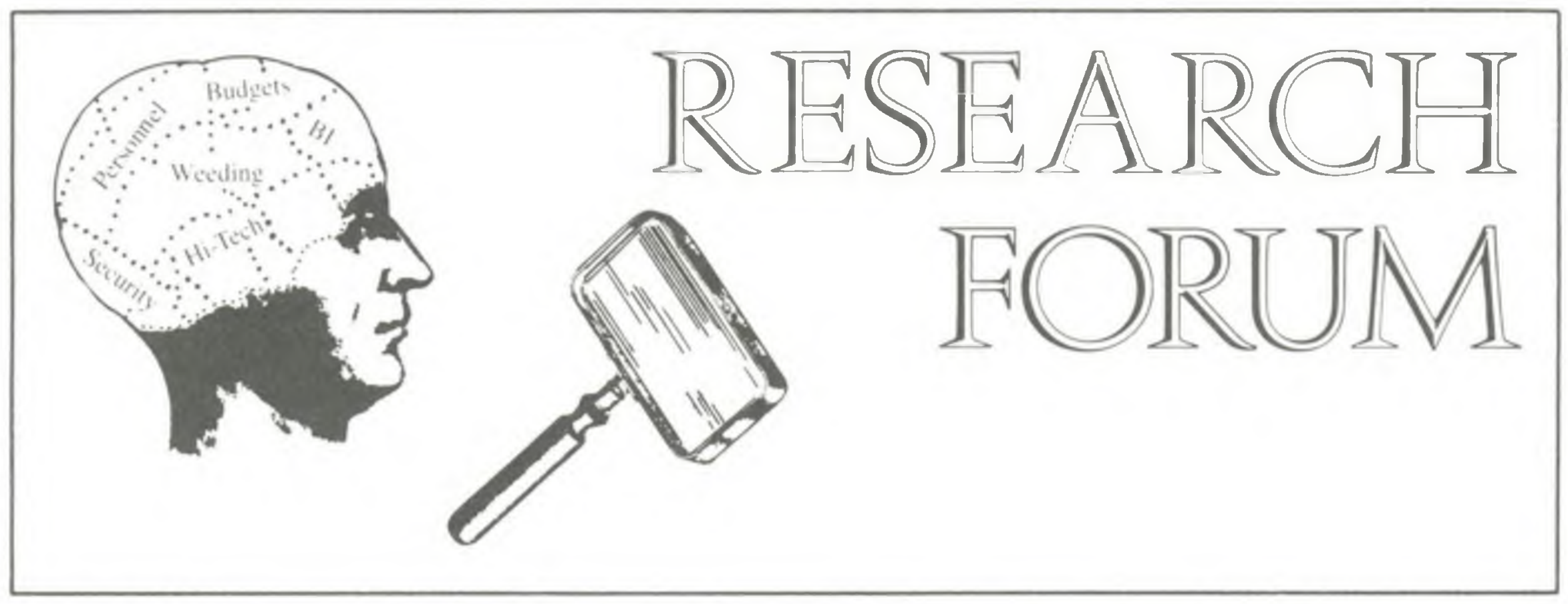

\title{
Librarians and historians at the American Historical Association
}

\author{
By Joyce Duncan Falk \\ History Reference Librarian and Data Services Coordinator \\ University of California, Irvine
}

At the annual meeting of the American Historical Association, the Association for the Bibliography of History sponsored three panels related to historians' use of library resources. At one session three historian-librarians presented their views on “Historians' and Librarians' Approaches to Research: Implications for Educating Historians, Librarians, and Archivists." Stephen K. Stoan elaborated on the points made in his article, "Research and Library Skills," College and Research Libraries 45 (March 1984):99-109, by recounting his experiences as a graduate student and history instructor. (A summary of his presentation is given on p. $503-E d$.).

In my "Reply to Stephen Stoan" I agreed with Stoan's brief that librarians should understand and articulate the distinction between library skills and research and with his explanation of the importance of non-library resources in historical research, for example, graduate school experience, colleagues, footnotes, and textbooks. I believe, however, he has overdrawn the misunderstanding between librarians and historians as he has oversimplified and misrepresented librarians' attitudes and practices. Stoan cautions librarians against misjudging the competence of history professors to teach students bibliography and goes to the opposite extreme of uncritically accepting historians' research habits and of assuming that anything they publish is ipso facto good research.

Stoan draws an artificial distinction between the historian's use of footnotes and textbooks and the librarian's use of indexes and encyclopedias; in truth, today's librarian knows the value and use of all of these. Stoan criticizes the librarian's highly systematic approach to research without recognizing that librarians adjust their presentations to the level of the student and that they do take into account the non-systematic aspects of research. While understanding the virtues of serendipity, browsing, gradual accumulation and random association of ideas, backtracking, and other nonsystematic "methods," we should also realize that they are often used by scholars simply for pleasure, out of habit, from lack of familiarity with tools that would be useful, and from lack of effort in using available resources.

I suspect that most librarians know professors amazingly well-versed in the bibliography of their field and knowledgeable about the broad field of history bibliography as well, but it is unwarranted to assume that all professors are so equipped, even if they did receive what they consider excellent training in graduate school. It is irresponsible to encourage the general assumption that professors are competent to teach or interested in teaching the bibliography and library use skills that their students need to know.

Stoan and I agreed that graduate students are the most likely to need and to benefit from bibliographic instruction; but, contrary to Stoan's arguments, I pointed out that at some institutions undergraduate courses do require independent library work. Furthermore, librarians are usually able to distinguish among courses and professors, tailor bibliographic instruction to the particular 
class, and accept the fact that some classes do not need it at all.

In addressing the question of the impact of online database searching on bibliographic instruction in history, I noted that it varies depending on the personality and interests of the professor, the research topics in a class, and the other resources available for the subject. Whereas the literature on humanists' attitude toward use of online searching cites the need for an intermediary as an obstacle to such usage, I have not experienced reluctance on the part of history professors to discuss their research topics and participate with the librarianintermediary in search strategy development and performance of the search. Teaching history students and faculty about online database searching is a significant responsibility of the instructional librarian. The increasing availability of online searching by specialist intermediaries, the growth in the number of systems for searching by the individual researcher, and the rapid spread of online catalogs make bibliographic instruction imperative for the history student's success in college and in later professional life. There is little cause to fear that librarians will misrepresent library use and the gathering of a list of citations as research.

The implications of this discussion for the education of librarians are that library school students preparing for academic librarianship should have genuine research experience in a subject matter, be thoroughly current in instructional theory and practice, and pursue continuing education in a subject area through reading current research and through participating in professional meetings. By reading Stoan's article in $C \mho R L$ they can heighten their awareness of the variety of aspects of research and of the pitfalls of a narrow interpretation of it in library instruction presentations.

For the education of historians, graduate research methods courses must include current library, archival, and other information technology as well as new research aids and resources. Stoan overlooks the fact that the majority of historians presently engaged in the training of students have themselves not been trained in these current resources and techniques of information retrieval, and are therefore unlikely to provide adequate instruction in these crucial areas. Perhaps the next generation of historians will not be in need of so much assistance from librarians. Care must be taken to avoid the attitude, illustrated in some of Stoan's remarks, of the self-sufficient, omniscient, even arrogant professor who believes the techniques and resources he learned in graduate school and from research in a narrow specialty are all his students need to know. Instead, future historians should be encouraged to call upon any and all persons-even librarians-who have other knowledge, resources, and approaches to the subject.

The third panelist, Frederick J. Stielow (College of Library and Information Services, University of Maryland), in a paper titled "Continuities and Dis- continuities in the Training of Librarians, Historians, and Archivists," traced the historical reasons for the increasing separation of American historians from command of bibliographic and library skills. The two fields of history and librarianship had similar roots and began at about the same time, but they developed different educational philosophies and curricula. Now the fields need to partake of the knowledge and methodologies of each other. One area in which this is happening is archival education.

\section{Sources}

Kirkendall, Carolyn, ed. "Dialogue and Debate: Online Reference Services' Impact on Bibliographic Instruction," Research Strategies 3 no.1 (Winter 1985):40-43; "Dialogue and Debate: To Teach Manual or Online Searching," ibid., 3, no.2 (Spring 1985):93-94.

McCarthy, Constance. "The Faculty Problem," Journal of Academic Librarianship 11, no.2 (July 1985): 142-45.

McCrank, Lawrence J. "Public Historians in the Information Professions: Problems in Education and Credentials," Public Historian 7 no.3 (Summer 1985):7-22.

Smalley, Topsy N., and Stephen H. Plum. "Teaching Library Researching in the Humanities and the Sciences: A Contextual Approach," in Cerise Oberman and Katrina Strauch, eds., Theories of Bibliographic Education: Designs for Teaching (New York: Bowker, 1982), pp. 135-70.

Stoan, Stephen K. "Research and Library Skills: An Analysis and Interpretation," College and Research Libraries 45, no.2 (March 1984):99-109.

Vincent, C. Paul. "Bibliographic Instruction in the Humanities: The Need to Stress Imagination," Research Strategies 2, no.4 (Fall 1984):179-84.

\section{RBMS bylaws change}

At the ALA Annual Conference in New York the ACRL Board of Directors approved the following amendment to Article VII (Committees) of the Rare Books and Manuscripts Section's bylaws:

"Sec.3. Discussion Groups. Discussion Groups to discuss issues and topics of interest to the Section may be authorized by the Executive Committee. The name and purpose of the discussion group shall be specified at the time of authorization. The chair of the discussion group will be appointed by the chair of the Section. A discussion group may be discontinued or declared inactive by the Executive Committee."

The complete RBMS bylaws may be found in CむRL News, April 1981, pp. 107-8. 


\title{
Historians and librarians: A response
}

\author{
By Stephen K. Stoan \\ Head of Reference \\ Wichita State University
}

I presented what could be called a case study of one historian-myself-and of his training and personal philosophy of teaching. The major points I emphasized were: 1) I personally received excellent bibliographic training in graduate school, consisting of six credit hours of coursework on the historical literature of Latin America taught by two professors of history; 2) given this training, I regarded myself as competent to deliver bibliographic instruction to my own students; 3 ) the circumstances of my teaching were such that I preferred to give library assignments only to my graduate students, to whom I did give bibliographic guidance; 4) given my training, I would have seen no good reason to have a librarian give bibliographic instruction in my courses; 5) I was fully aware that other professors, depending on their circumstances and personal philosophies of pedagogy, might teach in a different way and desire bibliographic instruction by a librarian, which I would support; and 6) my personal use of bibliographic tools, even though I knew them very well, was occasional because the internal logic of my information-seeking made other techniques of gathering bibliography generally more useful.

The points I hoped to convey by making the presentation in this way were as follows: 1) we should be cautious about assuming that college professors are all ill-prepared in bibliography; 2) many professors are competent to give bibliographic guidance to their students; 3 ) we must be sensitive to professors' prerogatives in organizing and teaching their courses as they see fit, for not only does the university make them accountable for that activity but this is a powerful tradition within the academy that professors themselves are extremely sensitive to; 4) there may be legitimate and defensible reasons why some professors do not desire the services of librarians; 5) some professors may seek the help of librarians, which is also legitimate and defensible; and 6) we must guard against making blanket assumptions about the quality of academic research or teaching, since we cannot prove empirically that using this or that index more or knowing of the existence of this or that bibliography affects the quality of research.

I argued, then, that though librarians ought legitimately to alert faculty and students to the existence of indexes and other specialized bibliographies, we have no choice but to leave them free to use, not use, or even forget those tools as they see fit. That someone is unaware of a particular tool does not necessarily mean that he was never taught it (by a librarian or a faculty member), only that he may have forgotten it. That someone uses a tool only sporadically does not mean that he is not using it "enough" to be a good researcher or teacher, only that his personal information-seeking behavior is such that he does not think he needs it more.

Librarians, therefore, should be guarded about blanket criticisms of the research skills or teaching techniques of the faculty, the more so when we ourselves were not hired by the university because of our recognized expertise in scholarly research or pedagogy.

\section{Workshop on fund-raising for law librarians}

On Thursday, July 10, 1986, the American Association of Law Librarians sponsored an all-day workshop on fund-raising for law librarians as part of their 79th Annual Meeting in Washington, D.C., organized by Carol A. Roehrenbeck, law librarian at Nova University. I had been invited to be one of the speakers at this workshop, addressing the topic "Embarking on the Fund-Raising Program."

Other speakers and panelists included Gerald Crane, executive vice president for alumni affairs, City College of New York; Diana Vincent-Davis, director, New York University School of Law Li- brary; James B. Hoover, law librarian, Columbia University Law Library; Julius Marke, law librarian, St. John's University; Alfred Coco, law librarian, University of Denver; and Morris Cohen, law librarian, Yale University School of Law. Presentations and discussions focused on the principles and basic techniques of fund-raising, campaign strategies, and how to build a funding file. This was followed by a discussion on grantsmanship led by Sandra Coleman, law librarian at Harvard University, and round table discussions of two actual grant proposals. The workshop participants were assisted in this endeavor by a panel of experts: Sally 
Jones, foundations and research director, Statue of Liberty, Ellis Island Foundation; Lee Kimche McGrath, director, Art in Embassies Program, U.S. State Department; and Harold Cannon, director, Office of Preservation, National Endowment for the Humanities.

Much useful and practical information was provided during the workshop and all participants gained new insights into the art of fund-raising, including gift programs, grant proposal preparation, friends of libraries, building and endowment fundraising campaigns, and, most especially, how to understand and work successfully with governmental, private and corporate funding sources. Hannelore B. Rader, ACRL President.

\section{Librarians and international}

\section{development: Getting involved}

\author{
By Alice Spitzer \\ Public Services Librarian \\ Washington State University
}

\author{
and Elaine Brekke \\ International Development Liaison Librarian \\ Washington State University
}

\section{A workshop on overseas consulting at WSU.}

L Librarians and International Development: Getting Involved" was the title of a workshop held May 7-8, 1986, by Washington State University Libraries in Pullman, Washington. The workshop was designed to inform librarians and to encourage greater library participation in this land grant university's international development projects at home and overseas.

Although WSU librarians have been engaged in international development since the 1950s, there has been a great upsurge of activity in recent years. Librarians who work directly with projects and those who recently returned from overseas assignments in Jordan, Yemen Arab Republic, and Lesotho wanted to share their experiences. The resulting two-day workshop gave a broad introduction to the topic of librarians and international development. Among the subjects covered were what it means to be a library consultant overseas, crosscultural communication, stateside library support services for international development projects, project design, implementation and evaluation, culture shock, and how international development fits into the WSU Libraries' overall goals. Guest speakers were drawn from WSU Libraries, WSU departments and the University of Idaho. A combination of lectures, panel discussions, films, role playing, and social activities kept participants on their toes.

Jan Noel, deputy director of WSU's International Program Development Office, gave a challenging presentation on project design which had the participants actively involved in the process of sending a hypothetical library consultant to another country. The session participants were divided into groups in order to explore the various viewpoints of the many agencies (host government, donor, contractor, campus office) that were involved in the project.

Information presented by consultants who had returned from overseas assignment exposed participants to the challenges and rewards of working abroad. A lively discussion followed where panelists compared and contrasted their experiences. 